\title{
Saber-sheath trachea in a patient with severe COPD
}

\author{
Pichapong Tunsupon, Samjot Singh Dhillon, Kassem Harris, Abdul Hamid Alraiyes
}

Department of Medicine, University at Buffalo State University of New York School of Medicine and Biomedical Sciences, Buffalo, New York, USA

\section{Correspondence to} Dr Pichapong Tunsupon, ptunsupon@gmail.com

Accepted 10 February 2016

\section{DESCRIPTION}

An 86-year-old man was evaluated for chronic cough and right lower lobe (RLL) mass. His medical history was significant for severe chronic obstructive lung disease (COPD). He had smoked one pack of cigarettes daily for 55 years. He had a barrel-shaped chest and diminished breath sounds in bilateral lungs were heard. CT of the chest noted RLL mass and abnormal configuration of the trachea (figure 1). Bronchoscopic examination showed an enlarged non-collapsible horseshoeshaped trachea (figure 2). Endobronchial ultrasound with fine-needle aspiration of the left paratracheal lymph nodes revealed squamous cell carcinoma. A diagnosis of stage IIIb lung cancer was established. The patient was referred to the oncology department, for further management.

We demonstrate radiographic and bronchoscopic features of saber-sheath trachea in a patient with severe COPD and concurrent primary lung cancer. Intrathoracic coronal narrowing and sagittal widening of the trachea characterise saber-sheath trachea, which is commonly associated with severe obstructive lung diseases, for example, chronic bronchitis, emphysema, hyperinflation and bronchiolitis obliterans syndrome after lung transplantation. ${ }^{1} \mathrm{~A}$ tracheal index (the ratio between coronal and sagittal diameter of the trachea at the same level) of less than two-thirds has $92.9 \%$ specificity, but $39.1 \%$ sensitivity, to diagnose severe cases of COPD. ${ }^{2}$ The pathophysiological mechanisms of saber-sheath trachea are due to repetitive cartilaginous injury from excessive coughing, and elevated intrathoracic pressure. These mechanisms cause degeneration and ossification of the cartilage leading to chronic remodelling, calcification and bending of the tracheal cartilage. ${ }^{3}$ Cases of air leaking during endotracheal intubation were reported because the circular-shaped balloon could not approximate the sagittal elongation of the stiff tracheal wall. ${ }^{3}$ Laryngeal mask airway is an alternative option to maintain adequate mechanical ventilation. It is important for physicians to recognise this clinical

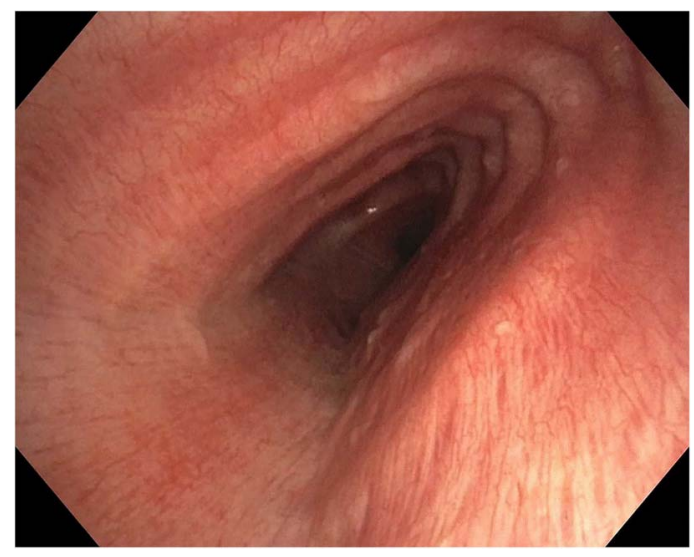

Figure 2 Bronchoscopic examination demonstrates a saber-sheath trachea. Elevated intrathoracic pressure indirectly promotes mechanical microinjury to the non-cartilaginous part of the trachea, subsequently leading to chronic remodelling of the tracheal cartilage.

\section{Learning points}

A saber-sheath trachea is characterised by a normal C-shaped extrathoracic trachea with abrupt coronal narrowing and sagittal widening of the intrathoracic trachea. This condition is commonly associated with severe obstructive lung diseases, for example, chronic bronchitis, emphysema, hyperinflation and bronchiolitis obliterans syndrome after lung transplantation.

- The pathophysiological mechanisms of saber-sheath trachea are due to repetitive cartilaginous injury from excessive coughing, and elevated intrathoracic pressure. These mechanisms cause degeneration and ossification of the cartilage leading to chronic remodelling, calcification and bending of the tracheal cartilage to form a rigid non-collapsible trachea.
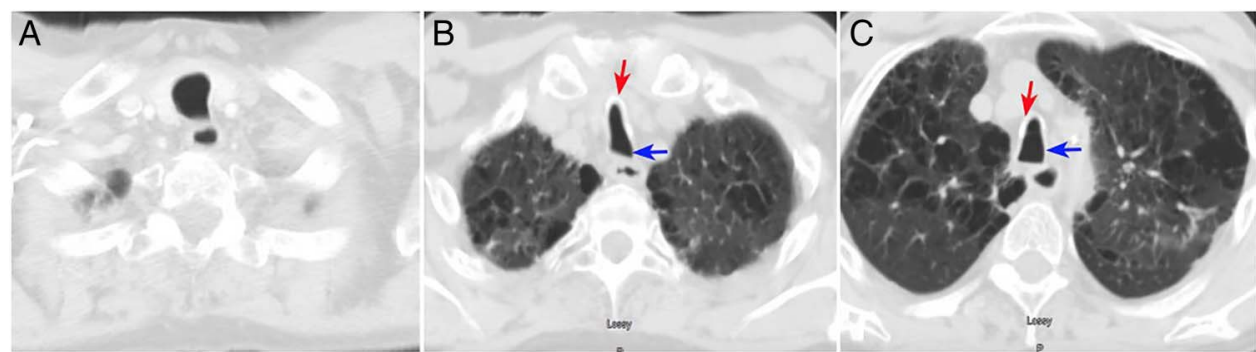

Figure 1 Axial CT of the chest demonstrates a normal C-shaped extrathoracic trachea (A). Different slice of chest CT from the same patient shows a saber-sheath intrathoracic trachea ((B) and (C), blue arrow) and calcified tracheal cartilage due to a chronic remodelling process ((B) and (C), red arrow). This condition is also known as a horseshoe-shaped trachea. 
entity for a proper diagnosis. There is no specific treatment for saber-sheath trachea.

Competing interests None declared.

Patient consent Obtained.

Provenance and peer review Not commissioned; externally peer reviewed.

\section{REFERENCES}

1 Hayes D Jr, Ballard HO. Saber-sheath trachea in a patient with bronchiolitis obliterans syndrome after lung transplantation. Chron Respir Dis 2009;6:49-52.

2 Tsao TC, Shieh WB. Intrathoracic tracheal dimensions and shape changes in chronic obstructive pulmonary disease. J Formos Med Assoc 1994;93:30-4.

3 Ismail SA, Mehta AC. "Saber-sheath" trachea. J Bronchol Intervent Pulmonol 2003;10:296-7.

Copyright 2016 BMJ Publishing Group. All rights reserved. For permission to reuse any of this content visit http://group.bmj.com/group/rights-licensing/permissions.

BMJ Case Report Fellows may re-use this article for personal use and teaching without any further permission.

Become a Fellow of BMJ Case Reports today and you can:

- Submit as many cases as you like

- Enjoy fast sympathetic peer review and rapid publication of accepted articles

- Access all the published articles

- Re-use any of the published material for personal use and teaching without further permission

For information on Institutional Fellowships contact consortiasales@bmjgroup.com

Visit casereports.bmj.com for more articles like this and to become a Fellow 